\title{
Developments in history education in Ghana
}

\author{
DOI: http://dx.doi.org/10.17159/2223-0386/2021/n25a5
}

\author{
Gideon Boadu \\ Excelsia College, Sydney, Australia \\ gideon.boadu@excelsia.edu.au \\ Orcid: 0000-0003-3212-1096
}

\section{Abstract}

This article employs historical records, cultural traditions, and insights from recent interviews with history teachers to trace the beginnings of history teaching and the political landscape that has shaped school history and history curricula in Ghana. The article argues that history education in Ghana has survived the ravages of time, Western historiographical ideals and imperialist ambitions as well as politically motivated legislations and reforms. The article concludes that history education is regaining its grounds in Ghanaian schools and raises implications for teacher education and resource provision in schools. The article contributes to an understanding of the evolution of history education in Ghana and the impact of colonial and political forces on curricula, teaching and learning of African history.

Keywords: Ghana; Education reforms; History curriculum; History education; Teacher education; Schools 


\section{Introduction}

Perspectives on the aim of history teaching in schools as expressed by historians, educators, students, politicians, and the public are many and contested (see Rautiainen, Räikkönen, Veijola \& Mikkone, 2019; Chapman, Burn \& Kitson, 2018). Yet, in many places across the world, history as a school subject is a powerful medium for intellectual and democratic training and values acquisition which positions students to understand society-in-context and contribute towards decision making. In Ghana, history is increasingly regarded as a tool for the development of critical minds, for deriving veritable lessons for the present and future, and for the formation of people who can contribute effectively to national development (Cobbold \& Oppong, 2010; Adjepong, 2013). Understanding a community or a nation's history sets the stage for a clearer understanding of present social, economic, and political conditions. School history, therefore, should serve the common good by developing active and democratic citizens who can attend to present-day issues using their understanding of past developments as a building block (Barton \& Levstik, 2004).

Ghanaians are interested in the past and current achievements of their nation, the political and socio-economic organisation, and the cultural heritage of Ghana ${ }^{1}$ and its people, thus making history an essential ingredient in the nation's development efforts. Despite Ghana's long and rich historical background, there has not been consistent attempts to document the history of history education in Ghana and changes in history curricula except the pioneering work of Buah (2002) and Dwarko (2007) and the more recent work of Adu-Gyamfi and Anderson (2021). This article delves into the historical records and cultural traditions to trace the beginnings of history teaching and the transformations history education has undergone from precolonial times to the present. Unlike the 'traditions' approach adopted by Adu-Gyamfi and Anderson (2021), this article discusses history education in Ghana and the political landscape that has shaped school history, as well as the pace, direction, and focus of history teaching, using a largely chronological approach. This article contributes to an understanding of the nature of history education in Ghana since relatively little is known about history teaching in Ghana and Africa in general. The article also contributes to a clearer understanding of the impact of colonial and political forces on curricula, teaching, and learning of African history. To

1 Ghana, until independence in 1957, used to be called the Gold Coast. This name was given by early European traders upon the discovery of large amounts of gold which they coveted for their commercial interests. 
achieve a systematic presentation and understanding of the main argument of this article, a brief historical overview of education in Ghana precedes the discussion.

\section{Overview of education in Ghana}

This section provides a brief background to educational developments in Ghana from precolonial times to date. The aim is to introduce the reader to the political, historical, and contemporary context within which history education is conducted to enable the reader to appreciate the complexities surrounding the teaching and learning of history in Ghana.

Ghana has a rich tradition of education dating as far back as the pre-colonial times. In pre-colonial Ghana, the system of education was primarily traditional in nature. It was based on the values of obedience and apprenticeship whereby the elderly taught the young ones to assume roles and responsibilities in the traditional community. Many children accompanied their parents to the marketplaces, farms, and other places of work and learned directly under their instruction. Parents were responsible for ensuring that their children learned essential moral behaviours that accorded with societal standards and acquired practical skills through observation and learning by doing. The norms, taboos, and regulations of individual communities served as the guide for parenting and socialisation. Generally, the central focus of education during this time was on domestic, character, and practical training for the growth and continuity of society, with the home serving as the main and immediate agency responsible for the education of individuals.

The sixteenth century saw the introduction of a Western form of education which began following the arrival of European merchants who established schools as part of the means to advancing their economic interests. Historians observe that the foremost form of school education, which became known as Castle Schools, took place in the forts and castles that were built along the coastal towns by the merchants where their children ${ }^{2}$ as well as children of some Ghanaian chiefs and famous African traders were educated (Amenumey, 2008; Ampadu \& Mohammed, 2006). Prominent among the castle schools were those established by the Portuguese in 1529 and the British in 1694 in the Elmina and Cape Coast castles respectively. This form of education was technically oriented and more structured, as it followed a specific curriculum which featured subjects such as reading, writing, arithmetic, and religious education, as well as practical courses such as masonry, carpentry, sewing, and agricultural training. Teachers acquired professional training in these

2 The children which the European merchants had with local Ghanaian women were called Mulattoes. 
technical subjects (Abosi \& Brookman-Amissah, 1992). The castle schools were followed by Mission Schools which were established following the arrival of several missionary groups in Ghana including the Wesleyan, Basel, Bremen, Presbyterian, and Roman Catholic Missions during the 1830s. These schools were located in and around the coastal towns of Cape Coast, Dixcove, Anomabu, Accra and as far inland as Akropong (Gyedu, 2014). According to historians, the missionaries intended to provide schools where children could have access to education and be converted to Christianity in the process (Abosi \& Brookman-Amissah, 1992; Amenumey, 2008). The subjects taught were English grammar, catechism, arithmetic, bible studies, and the history and geography of Europe. Unlike the castle schools, the missionary education tended to train a clerical workforce and not many technical hands that could contribute to wide-scale development. The missionary societies spearheaded the provision of Western education in Ghana for much of the period before the twentieth century. However, education provision became an official policy of the British government in Ghana in 1850 and was institutionalised in 1852 following the passage of an Ordinance to regulate the structure and quality of education in Ghana (Abosi \& Brookman-Amissah, 1992; Amenumey, 2008).

When Ghana became a British colony in 1874, the colonial administration applied more systematic efforts to regulate education in the country. An Education Ordinance that was passed in 1882 for the entire British West African ${ }^{3}$ region aligned the system of education in the region to the British setup and provided grants-in-aid to both public and missionary schools based on their efficiency (Antwi, 1992). The twentieth century witnessed the full commitment of the British colonial government to the provision of schools in response to the rising number of children of school-going age (Bening, 1990). Each successive governor implemented policies that sought to improve access to, and quality of education in Ghana. Perhaps, the most comprehensive educational development under the colonial administration occurred during the governorship of Gordon Guggisberg (1919-1927). His Sixteen Principles of education advocated for the provision of universal primary education, quality secondary education, equity in education for boys and girls ${ }^{4}$, trade schools with a technical and vocational education, and quality university education

3 British West Africa was used to collectively refer to West African countries that were colonised by the British - Ghana, Nigeria, Sierra Leone, and The Gambia.

4 In indigenous Ghanaian cultures, boys had better chances to obtain formal education than girls. Girls were usually expected to undertake domestic duties in preparation for marriage. In present times, girls have increased opportunities to achieve formal qualifications in schools through policies that enhance the education of the girl child. 
for men and women. These principles constituted a major educational policy direction for Ghana until the 1960s (Amenumey, 2008; Kimble, 1963; McWilliam \& Kwamena-Poh, 1975). Even though critics argue Guggisberg discriminated against African medical officers (Gale, 1973), contributed to increased government expenditure on education (Williams, 1964), and did not operate in the best interest of the people of Ghana by virtue of him being a colonial official governor (Agbodeka, 1972), his contribution to improving the standard of education in Ghana cannot be missed even at present. The educational effort of the colonial government was complemented by the missionary societies who expanded the scope of their initial activities to include secondary education and teacher education. The colonial legacy of education in terms of the provision of schools continued after colonial rule and the gaining of independence in 1957 (Kwarteng, Boadi-Siaw \& Dwarko, 2012).

Developments in education continued after the first independent government came into office in 1951. The Kwame Nkrumah-led administration implemented two main objectives for the provision of education in Ghana. First was the extension of education to many parts of the country in order to widen access. Second, there was training and equipment of people with skills needed for administrative and industrial services. To achieve these objectives, the government designed policies such as the Accelerated Development Plan of Education of 1951, and the Education Act of 1961. With necessary modifications, these policies became the blueprint for Ghana's education for about two decades and produced some positive changes to the system that was inherited from the colonial administration (Kwarteng et al., 2012; Graham, 1971). After the overthrow of Kwame Nkrumah's government in 1966, several attempts were made by successive civilian and military regimes to improve the education sector. The National Liberation Council (1966-1969), the Progress Party (1969-1972), the National Redemption Council (19721975), the Provisional National Defence Council (1981-1987; 1987-1992), National Democratic Congress (1992-2000; 2009-2016), and the New Patriotic Party (NPP) (2001-2008; 2017-present) have all contributed to educational developments in Ghana.

\section{Brief overview of major educational reforms in post-independence Ghana}

The post-Nkrumah period witnessed a series of educational reforms. Committees were formed at various times to recommend changes to the structure of education in Ghana. Key among these committees was the Dzobo Committee of 1973. In 1974, the Dzobo Committee published a new report on the structure and content of education which reduced the number of years of pre-university education from 17 years to 13 years. Before 
this report, pre-university education in Ghana comprised a six-year primary school, which ushered students into a four-year elementary education. After successful completion, students proceeded to a five-year secondary school course and wrote the Ordinary Level examination. Pre-university education ended at the sixth form which had two stages Lower Six and Upper Six, after which students wrote the Advanced Level examinations for admission into the university. With the Dzobo report a six-year primary education was followed by a three-year junior secondary school, and a four-year senior secondary school (Ampadu \& Mohammed, 2006; Antwi, 1992). The recommendations were aimed at preparing people for the world of work. However, the recommendations did not yield the expected outcomes upon its implementation in a few experimental schools (Palmer, 2005). The Dzobo Committee report provided a foundation for the 1987 educational reforms under the Provisional National Defence Council. The 1987 reforms reduced the Dzobo recommendations further to twelve years. Primary and junior secondary school retained their six years and three years durations respectively while senior secondary school was reduced to three years. The Common Entrance Examination and the General Certificate of Education examination were also replaced with the Basic Education Certificate Examination (BECE) and the Senior Secondary School Certificate Examination (SSSCE) ${ }^{5}$ respectively. A priority focus area at the junior and senior secondary levels at the time was the development of technical and vocational skills (Ampadu \& Mohammed, 2006; Antwi, 1992).

Twenty years after the 1987 reforms, a new reform was introduced in 2007 to streamline education to meet the changing development needs of Ghana. Particular emphasis was placed on STEM education and the development of vocational, technical, and ICT skills in order to produce skilled human capital. The report on which the reform was based proposed a two-year kindergarten in addition to the existing 12-year pre-tertiary education (Republic of Ghana, 2002). In implementing this reform, the New Patriotic Party (NPP) government renamed the junior secondary school and senior secondary school levels as Junior High School (JHS) and Senior High School respectively. The number of years at the SHS level was increased from three to four years. However, the National Democratic Congress government who won the 2008 general elections, citing inadequate human and infrastructural resources, reversed the number of years of SHS education to three years. At

5 The Senior Secondary School Certificate Examination (SSSCE) was changed to the West African Senior School Certificate Examination (WASSCE) in 2006. WASSCE is an international standardised examination organised by the West African Examinations Council for member countries - Ghana, Nigeria, The Gambia, Liberia, and Sierra Leone. 
present, the NPP government is undertaking curricular reforms at the basic and secondary school levels. The brief historical overview of education in Ghana shows that political interest has been a major force in determining the system and structure of education in the country.

Ghana's education system is centralised whereby major policy regulations are designed and implemented by statutory bodies such as the Ministry of Education and the Ghana Education Service with support from key stakeholders and professional associations. Currently (June 2021), the education structure comprises a two-year preschool, six-year primary, three-yearJHS, three-year SHS, and a three to four-year tertiary education as shown in Figure 1. Students write the Basic Education Certificate Examination (BECE) at the end of the ninth grade (JHS 3) which is used as the criterion for entry into the secondary level. Generally, candidates who successfully complete the BECE proceed to the SHS. Others enrol in technical and vocational institutions to acquire practical skills training, while some take up an apprenticeship ${ }^{6}$ or trade in the informal sector and proceed to the world of work. The secondary education level runs a three-year program and is composed of SHS, vocational, and technical institutions. At the SHS level, students choose from six different course groups - General Science, General Arts, Visual Arts, Home Economics, Business, and Agricultural Science. Students select up to four elective subjects from one of the six courses in addition to four core subjects - Mathematics, English Language, Integrated Science, and Social Studies. SHS graduates, subject to sufficient passes in the West African Senior School Certificate Examinations (WASSCE), can then proceed to the tertiary level.

6 In Ghana, most trade apprenticeships take place in the informal sector. However, some forms of apprenticeship also occur as part of the training in vocational and technical institutions. For example, a person might learn carpentry under the tutelage of an established carpenter outside a school setting. Similarly, a student who is studying carpentry in a technical institute might undertake a period of apprenticeship with a qualified carpenter in the same way trainee teachers embark on teaching practice. 


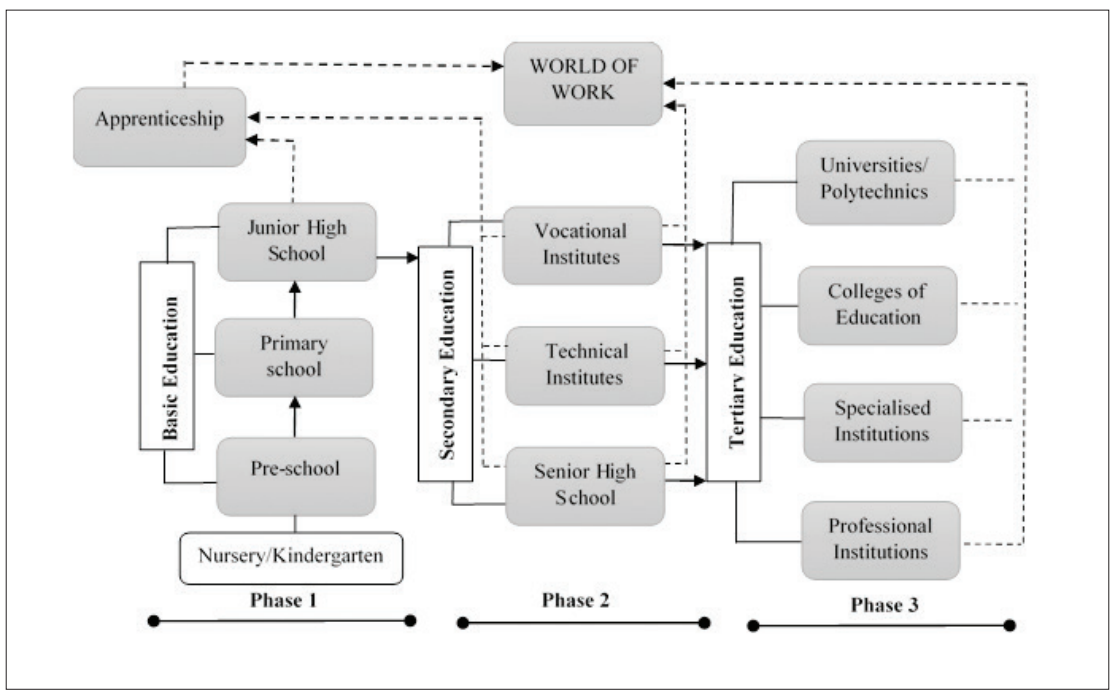

Figure 1: Structure of education in Ghana

\section{History education in Ghana}

This section begins with a brief history of African history to provide a premise for the discussion on history education in Ghana. This is done in light of the fact that notions about African history and historiography are directly linked to how our history is perceived and taught in schools (Boadu, 2020a).

The Ghanaian education system comprises several subjects, many of which have undergone significant revisions and reforms since the colonial era, in response to political influence. Among these subjects is history. Even though the history of Ghana covers several centuries and highlights several important developments, there has been lack of consistent focus on history teaching. Africa was generally regarded by early Western scholars as unhistorical due to the lack of systematic methods of recording and presenting events. In the view of these scholars, the only history worth recording about Africa is the history of European presence in Africa. A famous German philosopher, Georg Hegel, and Oxford historian Hugh Trevor-Roper were two figures known for discrediting Africa's significant past. Hegel, for instance, sought to dismiss Africa's history and rationality and described the great civilisations of North Africa as belonging to Europe and Asia. He wrote: 
"At this point we leave Africa, not to mention it again. For it is no historical part of the World; it has no movement or development to exhibit. Historical movements in it - that is in northern part - belong to the Asiatic or European World. What we properly understand by Africa, is the Unhistorical, Undeveloped Spirit, still involved in the conditions of mere nature" (Hegel, 1956: 99).

Years later, Hugh Trevor-Roper made a similar controversial argument during a public lecture in 1963 that was published in 1965 :

"Perhaps in the future there will be some African history to teach. But at present there is none, or very little: there is only the history of Europeans in Africa. The rest is largely darkness, ... and darkness is not a subject for history" (Trevor-Roper, 1965: 9).

However, evidence shows that before the 15 th century, there were indigenous ways of recording events and presenting past information in Africa (Akubor, 2015). In Ghana, traditional experts of the past known as praise singers recounted the stories of their society through various means including traditional music, folktales, rhetoric, and art forms (Fynn, Addo-Fenning \& Anquandah, 1991). In homes, parents and grandparents often educated children about the struggles and achievements of the past and presented them with useful lesson for the present and the future. A defining characteristic of this period was that oral accounts about the past were handed down from generation to generation (Falola \& Fleming, 2009). Aside from the moral lesson these oral accounts presented, they were also a medium for cognitive training since children were expected to understand, remember the accounts, and apply the lessons derived.

Following a series of nationalist developments in Africa and the diaspora in the 19th and 20th centuries, many African scholars have contested the Western notion and have, instead, emphasised a strong sense of African historical consciousness and erosion of the misconception that history is only learned from the history books (see Ranger, 2013; Ahuma, 1971; Nkrumah, 1970; Verharen, 1997). Also, some Western scholars, pointing to the achievements of Egypt and Carthage, have admitted that historical inquiry in Africa before the 18th century was more advanced than it was in Europe, with Africa's only challenge being the presence of dominant European powers (Black \& MacRaild, 1997). 
"Historical writing in ... the Islamic world of sub-Saharan Africa, ... was, in many ways, much more advanced than in medieval Europe. In Africa, the great civilisations of Egypt and Carthage had been considered part of the story of civilised history by Greek and Roman historians since Herodotus's day. The main problem for African civilisation has been the relative and growing strength of European powers" (Black and MacRaild, 1997: 28-29).

In Ghana, for instance, the first known Ghanaian attempt at the systematic documentation of Ghanaian history began with Carl Christian Reindorf and his book History of the Gold Coast and Asante, which covered more than three centuries (1500-1860) (Reindorf, 1895). Besides Reindorf, historians argue that the effort of many indigenous Ghanaians to investigate the past of the peoples, states, and kingdoms in Ghana during the precolonial and colonial periods were undermined by the efforts of Western historians (Adjepong \& Kwarteng, 2017). Consequently, the inaccurate Western views about African history, which were based partly on the absence of early written accounts and formal school settings and ill-informed understandings about African culture and practices, cannot be considered valid. Besides, Black and MacRaild (1997) argue that oral tradition was also central to Western history. The lack of formal methods of recording the African past in earlier times and the notion that Africa had no history prior to the contact with European nations led British authors to document Ghana's history from a British perspective, thus leaving few or no local accounts to be studied and appreciated (Baku, 1990; Reindorf, 1895).

Little has been written about the genesis of school history in Ghana. Analysis of historical records shows that the teaching of history in formal school settings began in the schools established by the missionaries and the British colonial government. In these schools, history featured in the curricula along with other subjects such as English Language, Arithmetic, Religion, and Geography. However, it was not until the 20th century that history became well placed in Ghana's school curriculum. During this period, most of the work of Ghanaian intellectual historians were focused on asserting a Ghanaian historical consciousness and encouraging the people to denounce the uncritical adoption of Western ways of life (see Sekyi, 1997; Ahuma, 1971; Hayford, 1969; Nkrumah, 1963). Particularly, Ghana's first president, Kwame Nkrumah, was committed to using history as a tool for developing African's conscience and personality. Nkrumah encouraged the teaching of history in both regular and technical schools, causing history to enjoy an 
enviable position in Ghana's school curricula (Adjepong \& Kwarteng, 2017). From the years following 1920 up to 1987, history was a core subject at Standard 7, senior school, and formed part of the Middle School Leaving Certificate Examinations. At the secondary level, history was an elective subject from Form 1 to Form 5 for students not in the science stream who attempted the School Certificate and General Certificate of Education Ordinary Level examinations. Students who proceeded to Form 6 continued to read history as it formed part of the subjects written at the General Certificate of Education Advanced Level examinations (Dwarko, 2007). When the 1987 educational reform was introduced, history began to lose its privileged position in schools. With the expunction of the middle school system, history was removed, integrated with other subjects, and taught as social studies at the basic school level. Similar developments occurred at the secondary school level where history ceased to be taught as a core subject and was instead made an elective subject for General Arts students (Dwarko, 2007). This could be a consequence of global developments during the 20th century, when history assumed a social science context in many regions across the world (Tilly, 1981; MacRaild \& Taylor, 2004; Skocpol, 1987). Changes to curricula have accompanied changes to history teaching in Ghana over time. An overview of these changes is discussed in the sections below.

\section{Curricula during the colonial period: pre-Guggisberg}

During much of the precolonial and colonial periods, the history curricula in both the missionary and public schools centred on the history of Great Britain. The emphasis on the achievements of Britain as a leading power in Europe at the time, came at the expense of studying Ghanaian and African history (Adjepong \& Kwarteng, 2017). At this time, Ghanaian historians had not focused much attention on the documentation of the history of Ghana. This was most likely influenced, and possibly impeded, by the increasing influence of the British in the country's administration and the attempts by local intellectuals to seek redress for several injustices in the administration of the country. Evidence suggests that as early as 1874, about 16 pseudo historical books had been published on Ghana by British authors and that this trend continued until 1900 with an average of two books published per year by British authors in Britain, and from a British perspective (Baku, 1990). As a result, although the students were African, none of the subjects they were taught, nor their content, dealt with Africa, which denied them the opportunity to study their own nation's history in school. As Adjepong and Kwarteng (2017) argue, the exploitation of history for the imperialist motives of the colonial government was evident. 


\section{Curricula during the colonial period: Guggisberg era}

The period of Gordon Guggisberg's governorship witnessed some improvements in history curricular as students were instructed in their local history, languages, and customs (Antwi, 1992). The institution of Achimota College in 1927 sought to extend this interest in African history and culture (Adu-Gyamfi \& Anderson, 2021). At this time, the content of history featured topics on Ghana, West Africa, and Egypt. It further addressed thematic areas in economic history, European history, and world history. The content, owing to its variegated nature, appealed to students from diverse backgrounds and therefore attracted much interest in the subject, making it very popular in schools (Dwarko, 2007). For instance. one of the key contributors to history teaching and curriculum development at Achimota College, W.E.F. Ward, was known for his dedication to sensitising the African youth about their own history, and his book, Africa before the white man came, drew useful links between several African states (Adu-Gyamfi \& Anderson, 2021).

\section{Curricula during post-Guggisberg and post-independence era}

The focus on the study of African history was short-lived, as the regional and local aspects of school history declined after Guggisberg's governorship. For instance, during the early 1950s, the secondary school history curricula (titled The Development of Tropical Africa) that were used across Commonwealth West Africa, contrary to its title, contained little content about Africa. Instead, in addition to content topics on Greek and Roman antiquity, they consisted of four main sections:

Section A: Early attempts at exploration, trade, etc.;

Section B: The slave trade, internal and overseas;

Section C: Exploration and colonization by Europe, and

Section D: Post-World War I developments in Anglophone countries of Tropical Africa (Buah, 2002: 141).

The justification for the little focus on Africa, the colonial government argued, was the lack of books on African history as well as the dearth of trained African history teachers. Buah (2002) further observes that, before 1966, six alternative curricula programs temporarily replaced the Development of Tropical Africa. Following this, schools adopted several other curricula until 1988. The post-1966 curricula of the West African Examinations Council 
$(\text { WAEC })^{7}$ for the General Certificate of Education/School Certificate comprised two sections: World history from $\mathrm{AD}$ 1750, and West Africa from $\mathrm{AD} 1000$, which reduced the concentration on European history and allowed for a broader focus on West African history. Another positive feature of the curricula was that its focus on a short period (19181960s) allowed for a detailed exploration of African history which contributed to student interest in the subject. Consequently, the Ministry of Education and the WAEC adopted a West African Advanced Level history course that was a combination of the Cambridge High School Certificate and London Advanced-Level curricula. According to Buah (2002), the examinations feature two papers:

Paper 1: $\quad$ African History: Either

a) Ancient African Civilizations, or

b) Modern African Kingdoms and empires

Paper 2: $\quad$ One of the following:
a) European and British History (1830-1939)
b) Islamic History
c) World Affairs
d) USA (1783-1865) and
e) Russian History, (1935-1945).

The focus on Africa was welcomed for its educational value and the change it brought to the educational space. As at 2002, the history syllabus that was in operation focused on three main sections:

Part 1: Landmarks of African History to 1800 (Thematic)

Part 2: History of Ghana from earliest times to 1900

Part 3: History of Ghana since 1900 (Buah, 2002: 144).

This shows more focus on Ghana and Africa, but Buah (2002) argued that it was educationally not balanced in its focus on local history and that it was too prescriptive and broad for examination purposes. Nevertheless, other historians maintain that the focus on Ghanaian and African history was to ensure pre-tertiary students' understanding of the

7 The WAEC was established in 1952 regulate high-stakes examinations for Ghana, Nigeria, Sierra Leone, Liberia, and the Gambia. 
meaningfulness and relevance of history (Adjepong \& Kwarteng, 2017). Compared to the 2010 senior high school history curriculum, which is still in operation, the thematic areas of the 2002 history curriculum have not changed much. The 2010 senior high school history curriculum is discussed further below.

\section{History at the SHS level}

At the SHS level, history currently falls under the General Arts course as an elective subject, together with other elective subjects such as French, Literature in English, Religious Studies, Economics, Geography, Government, Ghanaian Languages, and in some cases, Elective Mathematics. Out of these options, students study a maximum of four elective subjects together with the core subjects (Mathematics, Integrated Science, English Language, and Social Studies), depending on how the General Arts course is organised in schools. As such, even among General Arts students, subject combination options might differ within and among schools since not all students might opt to study history. History is therefore not a compulsory subject, and although some aspects of the subject appear in citizenship education and social studies at the primary, JHS, and SHS levels (Ministry of Education, 2010), historical knowledge gained through these subjects is not enough to provide the foundation for a higher-level study of the subject. Buah (2002) notes that, considering the organisation of the subject at the SHS level, a significant proportion of school children cannot get the opportunity to study history.

Currently, history has low enrolments at the SHS level compared to other General Arts elective subjects. Data from the WAEC shows that even though there was an upward trajectory in the number of students who studied history between 2006 and 2009, and between 2012 and 2015, this growth falls below that of those who studied other General Arts elective subjects, as shown in Table 1. Likewise, research indicates that both the image of history, and interest in it, are in decline (Dwarko, 2007; Adjepong, Oppong \& Kachim, 2017). Researchers have attributed the decline in the study of history to factors such as insufficient qualified teachers, memory-based teaching and learning strategies, the economic and technological dictates of the contemporary job market, government policy, and negative perceptions of the subject (Adjepong et al., 2017). Similarly, in my recent interview with SHS history teachers in Ghana, some of them expressed concerns about how students perceived job prospects in history. One teacher said, "The challenge is that most of the students think that when they do history, they will not get many job opportunities" (face-to-face interview, October 2017). 
In the post-colonial era, it is concerning that history is not more prominent in Ghanaian school curricula, given the controversies surrounding the study of African and Ghanaian history. It appears that even though Ghanaians are generally interested in remembering the past of their nation and celebrating their cultural heritage, their interest in the study of history in schools is not profound.

Table 1: Enrolment in WASSCE between 2006 and 2015

\begin{tabular}{lllll}
\hline Year & History & Government & Economics & Geography \\
\hline 2006 & 15,282 & 30,057 & 34,992 & 22,331 \\
2007 & 16,466 & 35,335 & 39,600 & 25,299 \\
2008 & 16,054 & 37,937 & 41,218 & 26,505 \\
2009 & 18,649 & 46,134 & 49,134 & 30,949 \\
2012 & 20,266 & 58,506 & 59,456 & 36,608 \\
2013 & 48,703 & 145,148 & 144,872 & 87,865 \\
2014 & 31,719 & 93,423 & 91,675 & 55,540 \\
2015 & 36,806 & 104,014 & 103,544 & 64,814 \\
\hline
\end{tabular}

\section{The current SHS history curriculum}

Ghana practises a top-down approach to curriculum development and implementation. In this approach, the National Council for Curriculum and Assessment designs and disseminates the history curriculum to schools. Teachers are expected to implement the curriculum as designed and presented to them in order to achieve its objectives. The current SHS history curriculum covers three years - SHS 1 to SHS 3 - and outlines the rationale, aims and objectives, contents and methods, profile dimensions, and assessment strategies to be employed for teaching the subject.

\section{Rationale}

The rationale for the teaching of history at the SHS level highlights the broader national aspiration for history and provides justification for the subject and the implementation of 
the curriculum. The rationale statement explains that SHS history is aimed at developing students' sense of awareness of the relevance of their national past in order to take pride in their national heritage and contribute to building on the achievements of the past generation. It further addresses the significance of harmony and tolerance for divergent cultures and viewpoints (Ministry of Education, 2010). The rationale reflects two underlying motives - pedagogical motive and nationalistic motive. The pedagogical motive draws attention to history being an analytical subject whose study should not be limited to memorisation. The nationalistic motive highlights the development of such dispositions as patriotism, national consciousness, and democratic participation which are useful to the nation's development efforts.

\section{General aims}

The aims and objectives of the curriculum are linked to the rationale. The general aims show that SHS history in Ghana seeks to equip students with the skills to locate, analyse, and interpret historical sources objectively. This means developing students' ability to investigate and critique historical information to arrive at informed conclusions. History also aims to equip students with the intellectual toolkit to redirect the study and interpretation of Ghanaian and African history from an insider perspective through a detailed study of the past. Further, it is aimed at developing students' awareness of Ghana's relationship with the wider world and their appreciation of the role of history in present and future development. The general aims are translated into specific objectives which recommend that teachers address the learning needs of students through active student involvement in order to achieve the specified general aims (Ministry of Education, 2010). This suggest that the subject needs to be portrayed in ways that are intellectually and practically engaging, consistent with constructivist ideology. To this end, teachers are expected to employ practical teaching-learning activities such as brainstorming, individual and group activity, role play, source analysis, class discussion, and field trips (Ministry of Education, 2010).

\section{Scope of content}

The contents of the SHS history curriculum are organised chronologically around three main sections: 
Section 1: Landmarks of African History up to AD1800

Section 2: Cultures and civilisations of Ghana from the earliest times to AD 1900

Section 3: History of Ghana and her relations with the wider world from

AD 1900 to 1991

These sections reflect significant themes on Ghana, Africa, and the world. A comparative analysis shows that there has not been a significant change to the central foci of the curriculum as the current curriculum focuses on themes that are similar to the syllabus that was in operation in 2002. Generally, the scope of content of the curriculum reflects the concerns of Buah (2002) that the syllabus is too expansive and prescriptive. Current history teachers share similar concerns. In a recent interview about history teaching in Ghana, history teachers described the curriculum as overcrowded with topics that cannot be effectively taught within the time allocated. One teacher, for instance, stated:

"The topics are too many and I have to finish them in two and half years. There are more than 40 topics and I need to teach everything. The way the syllabus is structured is posing a limitation on the real performance of teachers" (face-to-face interview, October 2017).

This suggests that even though the contents are useful, the scope and the time available for its completion could serve as a barrier to the realisation of the aims of SHS history. Recent research shows that even though many history teachers recognise the need for constructivist practices in the classroom, they tend to teach history as grand narratives in their attempt to achieve quick coverage of the curriculum (Boadu, 2020). In regard to teaching materials, the Ministry of Education's certified textbook titled History for secondary schools and several other textbooks written by private publishers are the main resources for history teaching. Teachers also rely on maps, historical sites, and other primary sources to facilitate their teaching.

\section{Profile dimensions}

The SHS history curriculum specifies three profile dimensions for teaching, learning, and testing in history - knowledge and understanding (KU), use of knowledge (UoK), and attitudes and values (AV). Teachers are encouraged to allocate a weight of $30 \%$ each to KU and AV, while UoK is allotted 40\% (Ministry of Education, 2010). The emphasis on UoK is 
to encourage students' application of historical knowledge in different contexts. The profile dimensions serve as the basis for assessment in history. The curriculum recommends a criterion-referenced assessment, meaning that teachers need to assess the extent to which students have attained each curriculum objective. The recommended forms of assessment such as projects, experiments, investigative study, practical work, and group exercises suggest emphasis on constructivist practices.

\section{History teacher education}

History teacher education in Ghana aims to prepare teachers who are equipped with knowledge and skills in the theory and practice of history teaching. History teachers at the SHS level usually complete a four-year university degree involving theories in historical content, teaching methodology, a twelve-week microteaching with their peers, and a twelve-week supervised teaching practice at a practice school to prepare them for the teaching profession. Alternatively, people with non-education degrees in history are required to complete a postgraduate diploma course in education to qualify as history teachers. The training and assessment of pre-service history teachers are based on a range of criteria including source analysis and interpretation which are aimed at developing their skills for effective teaching of the subject at the SHS level. Research shows that there is a deficit of qualified history teachers in Ghana (Oppong, 2012). Consequently, the system operates a hybrid approach whereby teachers of other related subjects such as social studies are sometimes engaged to teach history. Also, history teachers are mostly trained in two subjects (history and another subject). Therefore, it is common to find history teachers who teach another subject in addition to history. Further, there are cases where history teachers who studied history as a minor subject during their training teach history as their main or sole subject in schools. This situation makes the call for the training of specialist history teachers in Ghana more resounding (Boadu, 2020).

\section{Conclusion}

This article has historicised teaching of history in Ghana and drawn on current curricular and instructional developments to provide an understanding of the structure and position of history education in Ghana. The article has argued that history education in Ghana has gone through several stages as a result of the impact of dominant Western perspectives and imperialist ambitions as well as the implementation of politically motivated legislations 
and reforms. However, unlike the system of education under the colonial government and the immediate post-colonial regimes, history education in Ghana currently experiences appreciable consistency in structure, and its contents are streamlined to incorporate significant issues on Ghana and Africa. Even though the NPP government's decision to introduce history at the primary school for completely unprepared teachers is problematic, it is expected that this policy will increase enrolment numbers at the SHS level, where history is currently less patronised. History education is gradually regaining its grounds in Ghanaian schools for the first time since the 1987 education reforms. This growth has significant policy implications for adequate resource provision and for the training of specialist history teachers at both the primary school and SHS levels. 


\section{References}

Abosi, CO \& Brookman-Amissah, J 1992. Introduction to education in Ghana. Accra: Sedco Publishing Limited.

Adjepong, A 2013. Digging yesterday for the benefit of today and tomorrow: History as a storehouse of veritable examples for present and future use. African Journal of Interdisciplinary Studies 6(2):42-55.

Adjepong, A \& Kwarteng, KO 2017. Resuscitating 'clio' for the development of twentyfirst-century Ghana and beyond: Arguments in defence of the government's decision to reintroduce national history as a separate subject in the pre-tertiary school curriculum. Journal of Education and Practice 8(26):19-44.

Adjepong, A, Oppong, CA \& Kachim, KU, 2017. Crumpling the significant past: Actions and impressions for the 'fall' of history. Journal of Educational Management 8:237-280.

Adu-Gyamfi, S \& Anderson, E 2021. History education in Ghana: a pragmatic tradition of change and continuity. Historical Encounters, 8(2):18-33.

Agbodeka, F 1972. Sir Gordon Guggisberg's contribution to the development of the Gold Coast, 1919-27. Transactions of the Historical Society of Ghana 13(1):51-64.

Ahuma, A 1971. The Gold Coast nation and national consciousness. London: Frank Cass \& Co. Ltd.

Akubor, EO 2015. History, the historian and historical society of Nigeria@60: The journey so far and the road ahead. International Journal of Humanities and Cultural Studies 2(2):70-86.

Amenumey, DEK 2008. Ghana: A concise history from pre-colonial times to the 20th century. Accra: Woeli Publishing Services.

Ampadu, FO \& Mohammed, R 2006. Trends in education and school management. Accra: Edo Printing Press.

Antwi, MK 1992. Education, society and development in Ghana. Accra: Unimax Publishers.

Baku, DEK 1990. History and national development: The case of John Mensah Sarbah and the reconstruction of Gold Coast history. Research Review 6(1):36-48.

Barton, KC \& Levstik, LS 2004. Teaching history for the common good. New Jersey: Lawrence Erlbaum Associates.

Bening, RB 1990. A history of education in Northern Region, 1907-1976. Accra: Ghana Universities Press.

Black, J \& MacRaild, DM 1997. Studying history. London: Macmillan. 
Boadu, G 2020. "Hard” facts or "soft” opinion? History teachers' reasoning about historical objectivity. Journal of International Social Studies 10(1):161-186.

Boadu, G 2020a. Historical significance and the challenges of African historiography: Analysis of teacher perspectives. Pedagogy, Culture \& Society, https://doi.org/10.1080/ 14681366.2020 .1843070

Buah, FK 2002. The place of history in the reformed education. Transactions of the Historical Society of Ghana 6:139-145.

Chapman, A, Burn, K \& Kitson, A 2018. What is school history for? British studentteachers' perspectives. Arbor 194(788):1-14.

Cobbold, C \& Oppong, CA 2010. Re-echoing the place of history in the curriculum. International Journal of Educational Leadership 3(3):89-96.

Dwarko, DA 2007. History - our ailing subject: The need for revival in the 21st century. In: Amenumey DEK (ed) Challenges of education in Ghana in the 21st century. Accra: Woeli Publishing Services, pp.167--178.

Falola, T \& Fleming, T 2009. African civilisations: From the pre-colonial to the modern day. In: Holton R \& Nasson RW (eds) World civilisation and history of human development. Oxford, UK: Eolss Publishers, pp.123--140.

Fynn, JK, Addo-Fenning, R \& Anquandah, J 1991. History for secondary schools. Accra, Ghana: Ministry of Education.

Gale, TS 1973. Sir Gordon Guggisberg and his African critics. Transactions of the Historical Society of Ghana, 14(2):271-275.

Graham, C 1971. The history of education in Ghana. London: Frank Cass.

Gyedu, F 2014. Stakeholders' assessment of Ghana's post independence educational policies. Science Journal of Education 2(6):170-179.

Hayford, C 1969. Ethiopia unbound: Studies in race emancipation. London: Frank Cass \& Co Ltd.

Hegel, GWF 1956. Philosophy of history. New York: Dover Press.

Kimble, D 1963. A political history of Ghana: The rise of Gold Coast nationalism, 1850-1928. Oxford: Clarendon Press.

Kwarteng, KO, Boadi-Siaw, SY \& Dwarko, DA 2012. A history of the University of Cape Coast: Fifty years of excellence in tertiary education (1962-2012). Cape Coast: University of Cape Coast Press.

MacRaild, DM \& Taylor, A 2004. Social theory and social history. New York: Pelgrave Macmillan. 
McWilliam, H \& Kwamena-Poh, M 1975. The development of education in Ghana. London: Longman.

Ministry of Education 2010. Teaching syllabus for history. Accra: Curriculum Research and Development Division.

Ministry of Education 2019. History of Ghana curriculum for primary schools. Accra: National Council for Curriculum and Assessment.

Nkrumah, K 1963. Africa must unite. London: Heinemann.

Nkrumah, K 1970. Consciencism: Philosophy and ideology for de-colonization. New York: Monthly Review Press.

Oppong, CA 2012. Teaching and learning of history: An evaluation in the senior high schools in the Central Region of Ghana. Saarbrucken, Germany: Lambert Academic Publishing.

Palmer, R 2005. Beyond the basics: Post-basic education, training and poverty reduction in Ghana. Post-Basic Education and Training Working Paper Series-No 4. Center of African Studies, University of Edinburgh

Ranger, T 2013. Writing revolt: An engagement with african nationalism 1957-67. Harare: Weaver Press.

Rautiainen, M, Räikkönen, E, Veijola A, \&,Mikkone, S 2019. History teaching in Finnish general upper secondary schools: Objectives and practices. History Education Research Journal 16(2):291-305.

Reindorf, CC 1895. History of the Gold Coast and Asante: Based on traditions and historical facts, comprising a period of more than three centuries from about 1500 to 1860 . Basel: Basel Press.

Republic of Ghana 2002. Meeting the challenges of education in the twenty first century: Report of the president's committee on review of educational reforms in Ghana. Accra: Adwinsa Publication Limited.

Sekyi, K 1997. The blinkards. Ghana: Readwide Publishers.

Skocpol, T 1987. Social History and historical sociology: Contrasts and complementarities. Social Science History 11(1):17-30.

Tilly, C 1981. As sociology meets history. New York: Academic Press.

Trevor-Roper, H 1965. The rise of christian Europe. London: Thames \& Hudson.

Verharen, CC 1997. "The new world and the dreams to which it may give rise”: An African and American response to Hegel's challenge. Journal of Black Studies 27(4):456-493.

Williams, TD 1964. Sir Gordon Guggisberg and educational reform in the Gold Coast, 1919-1927. Comparative Education Review 8(3):290-306. 